\title{
MINDENKI AZT KAPJA, AMIT MEGÉRDEMEL? AZ ÉSZLELT IGAZSÁGOSSÁG KAPCSOLATA A SZOCIÁLIS KOMPETENCIÁKKAL ÉS JÓLLÉTTEL FIATALOK KÖRÉBEN
}

\author{
DO PEOPLE GET WHAT THEY DESERVE? \\ RELATIONSHIP OF PERCEIVED JUSTICE, SOCIAL \\ COMPETENCES AND WELL-BEING AMONG YOUTH
}

\author{
Bányai Blanka-Timea, Jancsó-Farcas Susana
}

\begin{abstract}
In the current research perceived justice, belief in a just world and sensitivity towards justice was examined among youth (high school and university students). In total 121 students participated in the study, aged between $15-26$ years, $59,5 \%$ female. The aim was to examine the relationship between belief in a just world and sensitivity towards justice and social competences, subjective well-being and academic performance. According to the results personal belief in a just world was associated with higher social competences (Pearson correlation coefficient $r=0,459 * *$, $\mathrm{p}=0,000)$, better academic performance $\left(\mathrm{r}=0.219^{*}, \mathrm{p}=0.020\right)$ and higher subjective well-being $\left(\mathrm{r}=0,363^{* *} ; \mathrm{p}=0,000\right)$. Significant differences were also revealed with independent sample $\mathrm{t}-$ tests. Furthermore, prosocial behavior was related to beneficiary $(\mathrm{r}=0,242 * * ; \mathrm{p}=0,010)$ and perpetrator sensitivity towards justice $(\mathrm{r}=0,304 * * ; \mathrm{p}=0,001)$.
\end{abstract}

Keywords: justice, belief in a just world, sensitivity toward justice, social competences, subjective well-being, academic performance

\section{Elméleti háttér}

Az igazságosság és az egyenlö bánásmód az emberi társadalom elengedhetetlen része, amely a közös együttélés alappilléreként is értelmezhető. Az emberek rendszerint a közvetlen társadalmi tapasztalatok alapján értékelő véleményt formálnak arról, hogy a társadalom, amelyben élnek mennyiben felel meg az igazságosság követelményeinek. Minden társadalomban kialakulnak olyan sztereotip igazságosság-felfogások, amelyek azt tartalmazzák, hogy milyennek kellene lennie egy jól müködő, a szabadságnak, egyenlőségnek, szolidaritásnak és más alapértékeknek megfelelő társadalomnak. Az igazságosság a modern társadalom egyik alapértéke és normatív követelménye.

A társadalmi igazságosság alapjai a sokféleség elismerése és a segítség kölcsönössége. Minden ember igénye, hogy viselkedésének, tetteinek, cselekedeteinek megfelelő bánásmódban részesüljön, munkáját elismerjék és megbecsüljék, és befektetett energiájának megfelelő jutalomban részesítsék. Az igazságos világba vetett hit is azon feltevésen alapszik, hogy mindenki azt kapja, amit megérdemel, így az emberek ezen elgondolás alapján cselekszenek. Az igazságosság és az igazságos világba vetet hit a társadalomban, a szociális kapcsolatokon keresztül fejlődik és fejti ki hatását. A családban és az oktatási intézményekben észlelt és tapasztalt igazságosság befolyással bírhat az egyének fizikai és mentális egészségére, befolyásolhatják viselkedésüket, cselekvéseiket, érzelmeiket, de ugyanakkor kihathat személyes és pszichológiai jóllétuikre is. 
A társadalmi berendezkedés legalapvetőbb követelménye, hogy igazságos legyen. Az igazságosság a közösségi lét alapja, amely olyan elvekböl áll, amelyek biztosítják az emberek közti együttmüködést. Ezek olyan közös elvek, amelyeket mindenki elfogad, hiszen az együttmüködés elönyös a társadalom számára (Rawls, 1997).

Az igazságosság észlelését olyan tényezők befolyásolják, mint a társas-társadalmi értékek, a döntésre vonatkozó szabályok, ezek alkalmazása a gyakorlatban, valamint ennek végkimenetele. A szakirodalom ezt procedurális igazságosságnak nevezi, mely a folyamat értékelését vonja maga után (Csepeli, Örkény, Székelyi és Barna, 2004). A döntések végeredményének megítélése esetén már disztributív igazságról beszélünk, mely során az egyén saját ráfordításait hasonlítja össze az általa elért eredményekkel. Ha a végeredmény nagyobb, mint a befektetett munka, igazságosnak fogja ítélni a helyzetet, fordított esetben azonban igazságtalanságot érezhet (Maxham és Netmeyer, 2002). Mind a procedurális, mind a disztributív igazságosság normákat ír elő az igazságtalansággal szemben. Ebből kifolyólag pedig létezik egy harmadik igazságosság is, a retributív igazságosság, amely fókuszában az áll, hogy milyen szankciók igazságosak a normákat megszegőkkel szemben (Csepeli, Örkény, Székelyi és Barna, 2004).

Az igazságosságot mindig az adott kultúra tükrében kell meghatározni. Ennek gyökerei azonban mélyebbről húzódnak, ugyanis az embernek alapvető pszichológiai igénye az igazság iránti vágy, vagyis az a hit, hogy egy olyan világban éljünk, amely kiszámítható és méltányos bánásmódot biztosít számunkra (Pikó és Pinczés, 2013). Lerner (1980) szerint ez az igazságos világba vetett hit hipotézisével magyarázható, mely egy olyan kognitív torzítás, amely segít a társas világban való eligazodásban. Az igazságos világba vetett hit mindenkinél egyéni módon fejlődik ki, de a társadalomnak köszönhetően eléri azt a hatást, hogy a szociális interakciók és kapcsolatokon keresztül fennmarad (Sallay, 2005).

A kutatások azt mutatják, hogy az általános igazságos világba vetett hit megkülönböztethető a személyes igazságos világba vetett hittől. Az általános igazságos világba vetett hit kifejezi azt a nézetet, miszerint a világ általában véve egy igazságos hely. A személyes igazságos világba vetett hit pedig azt hangsúlyozza, hogy az egyén sorsa igazságos, és életének eseményeit megérdemli. Az általános és személyes igazságos világba vetett hit együttesen fejezi ki azt a nézetet, miszerint a világ értelemmel rendelkezik. Ezen hit fejlödésében a családi, illetve baráti kapcsolatok fontos szerepet játszanak (Sallay, 2005). Lerner (1980) úgy gondolta, az igazságos világba vetett hitnek intrapszichikus szinten is fontos szerepe van, ugyanis ez segít értelmezni a világban történő igazságos és igazságtalan eseményeket, valamint hozzájárul pozitív önértékelésünk megőrzéséhez.

Az igazságosság vagy igazságtalanság megtapasztalása és az arra való érzelmi vagy viselkedésbeli reakció nem kizárólag a külső hatások eredménye, hanem ezt személyes érzékenységünk is befolyásolja (Pretsch, Risch, Ehrhardt és Roth, 2015). Az emberek szisztematikusan különböznek az igazságtalanság érzékelésére való hajlandóságukban, valamint az erre való kognitív, érzelmi és viselkedésbeli reakciók erősségében. Ezek az egyéni különbségek konzisztensek és időben viszonylag stabilak (Sabbagh és Schmitt, 2016). Az igazságtalanságra való érzékenység tehát egy személyiségvonásnak tulajdonítható, amely különbözik a többi személyiségi változótól. Azon személyek, akiknél magas ez az érzékenységi fok erősebb érzelmi reakciót mutatnak az olyan helyzetekben, ahol igazságtalanságot tapasztalnak, és ezen szituációkban olyan viselkedést fognak tanúsítani, amellyel megpróbálják az igazságtalanságot megváltoztatni (Schmitt, Baumert, Gollwitzer és Maes, 2010).

Az igazságossággal szembeni érzékenység négy részre bontható: áldozati érzékenység, megfigyelöi érzékenység, kedvezményezetti érzékenység és elkövetői érzékenység. Ezen típusok között a különbség abban rejlik, hogy milyen viselkedést és érzelmi reakciót mutatnak a személyek eltérö helyzetekben (Schmitt, Baumert, Gollwitzer és Maes, 2010). Míg az áldozati érzékenység antiszociális hajlandósággal jár, addig a kedvezményezett és az elkövető érzékenysége proszociális beállítottságot mutat. Azok a személyek, akik képesek a kedvezményezett szempontjából érzékelni az igazságtalanságot hajlamosak a büntudatra és a lelkiismeretfurdalásra. A kedvezményezett 
érzékenysége olyan proszociális személyiségjellemzőkkel társul, mint az empátia, a jókedv, a felelősségvállalás, a segítő magatartás, valamint a mások iránti aggodalom (Sabbagh és Schmitt, 2016).

Az észlelt igazságosság pozitív hatást gyakorol a tanulók teljesítményére és viselkedésére, hiszen azok a diákok, akik hisznek abban, hogy méltányosan fognak velük bánni, kevésbé tartanak a kudarctól, jobban bíznak a siker elérésében, bátrabban kísérleteznek és néznek szembe a kihívásokkal (Tomaka és Blascovich, 1994).

Egy 2018-ban végzett kutatás értelmében kétirányú kapcsolat fedezhető fel a viselkedési problémák és az osztálytermi igazságosság között. Egyrészt ezek a viselkedési problémák a tanár-diák kapcsolatok kedvezőtlen interakcióját eredményezik, másrészt a pedagógusok hozzáállása hatással van a diákok problematikus viselkedésére, amely továbbá a tanulási örömöt is befolyásolja (Ehrhardt, Pretsch és Schmitt, 2018). Főiskolai hallgatók körében szintén megvizsgálták, hogy a tanárok attitüdje, bánásmódja milyen érzelmi és magatartásbeli reakciót vált ki az érintett személyekből. 397 New Yorki végzős hallgatót mértek fel, amely következtében arra az eredményre jutottak, hogy a harag és az egyet nem értés a legjellemzőbb érzelmi és viselkedésbeli reakció, amit ezen egyetemista hallgatók tanúsítanak az igazságtalanság megtapasztalásakor (Chory, Houser és Horan, 2017).

A diákok részéről észlelt tanári képességek és viselkedési mintázatok hozzájárulnak az iskolai eredmények alakulásához, valamint befolyásolják a tanulással szembeni motivációt és a közösséghez való tartozást. Továbbá a tanárok diákjaikkal szembeni igazságos viszonyulása, az egyenlő bánásmód növeli az iskolai teljesítményt, a tanulási motivációt, valamint erősíti az osztályhoz való tartozás érzését (Molinari, Speltini és Passini, 2013). Az igazságos bánásmód hatással van a tanulók iskolával szembeni elkötelezettségére és tanulmányi teljesítményükre (Berti, Molinari és Speltini, 2010).

Egy 2018-ban végzett amerikai kutatás olyan személyeket vizsgált meg, akiket serdülőkorukban felfüggesztettek az iskolából. Ezek a személyek felnőttkorukban gyengébb teljesítményt mutattak, mint nem felfüggesztett társaik, azonban a kutatási eredmények azt mutatták, hogy az érintettek felfüggesztés nélkül is gyengébb teljesítményt értek volna el. A tanulmány az okokat az oktatási, illetve a bünügyi igazságszolgáltatásban kereste, arra a következtetésre jutva, hogy az igazságtalanság és a kirekesztés deviáns hajlamot eredményezhet. Ezen személyek a későbbiekben sem fejezték be tanulmányaikat és nagyobb százalékban kerültek összetüzésbe a törvénnyel (Rosenbaum, 2018).

$\mathrm{Az}$ iskolai környezetben tapasztalt igazságtalanság olyan negatív érzelmeket eredményezhet serdülőknél, mint a harag, a depresszió, a szégyen vagy a büntudat érzése. Ezek a negatív érzelmek gyakran alacsony affektív vagy kognitív jólléttel, valamint problematikus viselkedéssel társulnak. Az igazságossággal szembeni érzékenység, amely egy személyiségi vonás, moderálhatja ezeknek a negatív érzelmeknek a hatását, továbbá különböző viselkedési reakciókat indíthat be (Pretsch, Risch, Ehrhardt és Roth, 2015).

A szakemberek már korábban is felfigyeltek arra, hogy az emberek bizonyos érzelmi reakciókkal fordulnak az igazságosság felé, ám ezeknek a hatását nem igazán tanulmányozták szakszerüen. Weiss és munkatársai (1999) egyetemi hallgatókat vizsgált meg abban a tekintetben, hogy ezek a fiatalok hogyan reagálnak, milyen érzelmeket mutatnak a különböző igazságos és igazságtalan helyzetekkel szemben. A kutatás során a hallgatók olyan eseményekkel szembesültek, amelyek önmaguk, illetve mások irányába igazságosak, illetve igazságtalan kimenetelüek voltak. Ezt követően a résztvevők önmaguk értékelték a saját érzelmi reakcióikat. A kapott eredmények alapján, a kutatók arra a következtetésre jutottak, hogy az igazságosság egy érzelmi eseményként értelmezhető.

Csoportközi helyzetekben fontos szerepet játszik az igazságosság elveinek figyelembevétele és betartása. Az igazságosság észlelése, megtapasztalása fenntartja és javítja a szociális kapcsolatokat az együttmüködés, a proszociális viselkedés és a tisztelet kinyilvánítása által. Ezzel szemben az igazságtalanság negatívan hat a szociális kapcsolatokra, tiltakozást, szabotálást és deviáns hajlamot eredményezve (Conry-Murray, 2015). 
Egy egyetemista hallgatók körében végzett kutatás két csoportot alakított ki: a versengök csoportját, illetve a kooperáción-egyenlőségen alapulók csoportját. Mindkét csoport ugyanannak a problémának a megoldásán kellett dolgozzon, azzal a különbséggel, hogy míg az első csoportnak azt mondták, a csoport tagjai külön fognak jegyet kapni a munkájukra, amelyeket egymáshoz viszonyítanak majd, addig a második csoporttal azt az információt közölték, hogy a csoport minden tagja azonos jegyet fog kapni a munka elvégeztével. Az eredmények azt mutatták, hogy az a csoport, amely az egyenlöségre és a kooperációra törekedett, sokkal hatékonyabban oldotta meg a feladatot, eredményesebb volt a csoportközi kommunikáció, valamint nyitottabbak voltak egymás ötleteire. Ugyanakkor ezen csoport tagjai barátságosabbak, segítőkészebbek voltak egymással, amely jobb feladatteljesítményt eredményezett. Mindezek alapján levonható az a következtetés, hogy az egymás iránt tanúsított igazságos, egyenlőségen alapuló, kooperatív viselkedés sokkal jobb teljesítményt eredményez (Deutsch, 1986).

Az igazságosság észlelése és átélése nemcsak az érzelmek és a viselkedés megnyilvánulására van hatással, hanem nagymértékben befolyásolja a szubjektív és pszichológiai jóllétet is. Az iskolában és az egyetemen megtapasztalt igazságtalanság olyan negatív érzelmeket eredményezhet a tanulóknál, mint a harag, a depresszió, a szégyen vagy a büntudat. Ezen negatív érzelmeket általában csökkent érzelmi és kognitív jóllét kísér. A kedvezményezett érzékenysége szempontjából ez azt jelenti, hogy ha az illető diák mások kárára észlel igazságtalanságot és nagyon érzékeny erre, akkor büntudatot érezhet, amely következtében alacsonyabb jóllétet eredményezhet (Pretsch, Risch, Ehrhardt és Roth, 2015).

Több kutató is rájött arra, hogy a szubjektív jóllét alakulása nagymértékben függ a szociális kapcsolatoktól, az ezen kapcsolatokban megtapasztalt bánásmódtól és méltányosságtól. Lane (2000) szerint az emberi fejlődés, a szubjektív jóllét és az igazságosság fontos elemei a megfelelő színvonalú életnek. Ugyanakkor a családban és a baráti kapcsolatokban megtapasztalt igazságosság közvetítő szerepet játszik az igazságos világba vetett hit formálásában és a szubjektív jóllét alakulásában. Serdülők esetén a barátok jelentik a legfontosabb interperszonális kapcsolatokat, ezért feltételezhető, hogy abban az esetben, ha a fiatalok méltányosságot, igazságosságot tapasztalnak ezen kapcsolataikban, az nagymértékben kihat a szubjektív jóllétük kedvező alakulására. Minél inkább méltányosnak vélik családi légkörüket és baráti kapcsolataikat, annál inkább erősödik bennük az igazságos világba vetett hit, amely kedvező hatást fejt ki a szubjektív jóllét komponenseire is (Sallay, 2005).

Az oktatási intézményekben megtapasztalt igazságosság és az igazságos világba vetett hit jelentős hatást gyakorol a diákok fizikai és pszichológiai jóllétére is. Minél erősebb a diákok igazságos világba vetett hite, annál kevesebb iskolai stresszt és depressziós tüneteket fognak tapasztalni. Kamble és Dalbert (2012) indiai iskolákban végzett kutatásukban az igazságos világba vetett hit két dimenzióját vizsgálták: a személyes és általános igazságos világba vetett hitet. A kutatásban 278 tizedik osztályos diák vett részt, akik angol nyelvü magániskolákban tanultak. Az eredmények azt mutatták, hogy a diákok jóllétére kizárólag a személyes igazságos világba vetett hit volt hatással, tehát minél inkább úgy érezték a diákok, hogy szüleik és tanáraik igazságosan bánnak velük, annál magasabb jólléttel rendelkeztek.

Megállapítható, hogy összefüggés található az iskolai környezet és a jóllét között. Egy 2017-ben végzett kutatás kimutatta, hogy az osztálytermi légkör, az osztályközösség, a kollektív hatékonyság, valamint a megtapasztalt igazságosság kapcsolatba hozható a diákok szubjektív jóllétével. Az eredmények értelmében az osztálytermi kapcsolatok, a közösségérzet és az osztályban uralkodó procedurális igazságosság összefüggést mutat a diákok szubjektív jólléti állapotával (Capone, Donizzetti és Petrillo, 2017). 


\section{A kutatás célja és hipotézisei}

Jelen kutatásunk célja megvizsgálni, hogy az oktatási intézményekben, középiskolás diákok és az egyetemi hallgatók körében, az észlelt és tapasztalt igazságosság hogyan hat a tanulókra.

Hipotéziseink:

H1: A serdülök, illetve az egyetemisták esetén az igazságos világba vetett hit - mind az általános, mind pedig a személyes - összefüggést mutat a szociális kompetenciákkal.

H2: Az áldozati igazságosságra való érzékenység megnöveli a deviáns viselkedésre való hajlamot, míg a kedvezményezetti és az elkövetői igazságosságra való érzékenység összefüggést mutat a proszociális viselkedéssel.

H3: A személyes igazságos világba vetett hit összefüggést mutat a tanulmányi teljesítménnyel. Azon iskolás és egyetemista tanulók, akiknek magas a személyes igazságos világba vetett hitük, magasabb tanulmányi teljesítménnyel rendelkeznek.

H4: A személyes igazságos világba vetett hit összefügg a diákok és a hallgatók szubjektív jóllétével. A magasabb igazságos világba vetett hit magasabb szubjektív jóllétet eredményez.

\section{A kutatás résztvevői}

Kutatásunkban összesen $\mathrm{N}=121$ iskolás diák és egyetemista hallgató vett részt, életkorukat tekintve 15-26 év közöttiek $(\mathrm{M}=18,48 ; \mathrm{SD}=2,915)$. A résztvevők valamivel több, mint fele lány $(59,5 \%)$, illetve a nagyobb részük városi lakos $(58,7 \%)$. A megkérdezett iskolás diákok, illetve egyetemista hallgatók tanulmányi teljesítménye a romániai osztályozási rendszer alapján 5,00 és10,00 között $\operatorname{mozog}(\mathrm{M}=8,22 ; \mathrm{SD}=1,236)$.

\section{Felhasznált eszközök}

Kutatásunk során kérdőívek és skálák segítségével mértük fel a vizsgálni kívánt változókat.

A Dalbert, Montada és Schmitt (1987) által kidolgozott Általános Igazságos Világba Vetett Hit Skálát alkalmaztuk az általános világba vetett hit mérésére.

A személyes igazságos világba vetett hitet a Dalbert (1999) által kidolgozott Személyes Igazságos Világba Vetett Hit Skálájával vizsgáltuk.

Az igazságosságra való érzékenység négy típusát (áldozati, megfigyelői, kedvezményezetti és elkövetői) a Schmitt, Baumert, Gollwitzer és Maes (2010) nevéhez köthetö Igazságosság Érzékenységi Skálával mértük.

Az Általános Jóllét Skála rövidített 5 tételes magyar változatával (Well-Being Index-5, WBI-5 Susánszky, Konkoly, Stauder és Kopp, 2006) vizsgáltuk a személyek szubjektív jólléti állapotát.

A Szociális-Emocionális Kompetencia Kérdőív (SECQ - Zhou és Ee, 2012) öt alskálájával vizsgáltuk a személyek szociális kompetenciáit.

A Képességek és Nehézségek Kérdöiv (Strengths and Difficulties - SDQ - Goodman és Goodman, 2009) két alskálája, a proszociális, valamint a deviáns viselkedést mérő alskála került alkalmazásra.

Kutatásunkban kombinált stratégiát alkalmaztunk. Korrelációs stratégiát, valamint lineáris regresszió elemzést hajtottunk végre annak érdekében, hogy meghatározzuk a változóink közötti kapcsolatot. Az 
adatfelvétel online formában történt, az így megszerkesztett kérdőíveket líceumi diákok és egyetemi hallgatók töltötték ki. Az adatfelvétel teljesen anonim módon történt 2020 február és április között.

\section{A kutatási eredmények bemutatása}

Kutatásunk első hipotéziseként feltételeztük, hogy az általános és személyes igazságos világba vetett hit együttjárást mutat a szociális kompetenciákkal. Az általános világba vetett hit gyenge összefüggésben áll a kapcsolatkezeléssel és a kapcsolati döntéshozással, míg a szociális tudatossággal és a proszociális viselkedéssel nem mutat együttjárást. A személyes igazságos világba vetett hit szintén nem mutat összefüggést a szociális tudatossággal, de gyengén együttjár a proszociális viselkedéssel és a kapcsolatkezeléssel, valamint középerős összefüggést mutat a kapcsolati döntéshozással (lásd 1. táblázat).

1. táblázat. Az általános és a személyes igazságos világba vetett hit összefüggése a szociális kompetenciákkal

\begin{tabular}{|c|c|c|c|c|c|}
\hline & & $\begin{array}{c}\text { SECQ - } \\
\text { Szociális } \\
\text { tudatosság }\end{array}$ & $\begin{array}{c}\text { SECQ - } \\
\text { Kapcsolatkezelés }\end{array}$ & $\begin{array}{c}\text { SECQ - } \\
\text { Kapcsolati } \\
\text { döntéshozás }\end{array}$ & $\begin{array}{c}\text { SDQ - } \\
\text { Proszociális } \\
\text { viselkedés }\end{array}$ \\
\hline $\begin{array}{c}\text { Általános Igazságos } \\
\text { Világba Vetett Hit } \\
\text { Skála }\end{array}$ & $\begin{array}{l}\mathrm{r} \\
\mathrm{p}\end{array}$ & $\begin{array}{l}0,082 \\
0,388\end{array}$ & $\begin{array}{c}0,217 * \\
0,012\end{array}$ & $\begin{array}{c}0,222^{*} \\
0,018\end{array}$ & $\begin{array}{l}0,155 \\
0,101\end{array}$ \\
\hline $\begin{array}{c}\text { Személyes } \\
\text { Igazságos Világba } \\
\text { Vetett Hit Skála }\end{array}$ & $\begin{array}{l}\mathrm{r} \\
\mathrm{p}\end{array}$ & $\begin{array}{l}0,056 \\
0,557\end{array}$ & $\begin{array}{c}0,261 * \\
0,005\end{array}$ & $\begin{array}{c}0,459^{* *} \\
0,000\end{array}$ & $\begin{array}{c}0,224^{*} \\
0,017\end{array}$ \\
\hline
\end{tabular}

Többváltozós lineáris regressziós modell által meghatároztuk a független változóink, vagyis a szociális tudatosság, a kapcsolatkezelés, a kapcsolati döntéshozás, valamint a proszociális viselkedés hatását a függő változónkra, azaz a személyes igazságos világba vetett hitre. A kapott eredmények azt mutatják, hogy a független változóink 21,8\%-ban magyarázzák a függő változónk alakulását. A 2.táblázat értelmében a kapcsolati döntéshozás gyakorol a legnagyobb befolyást a személyes igazságos világba vetett hit alakulására $(\beta=0,529)$, míg a legkisebb befolyást a szociális tudatosság képviseli $(\beta=-0,243)$. A szociális tudatosság, valamint a kapcsolati döntéshozás statisztikailag szignifikáns prediktorok a függő változóra nézve, míg a kapcsolatkezelés és a proszociális vislkedés nem mutat szignifikáns előrejelzést a személyes igazságos világba vetett hitre.

2. táblázat. Többváltozós lineáris regresszió a személyes igazságos világba vetett hit alakulásáról a független változók függvényében

\begin{tabular}{|l|c|c|c|c|}
\hline & $\begin{array}{c}\text { Standardizálatla } \\
\text { n koefficiensek } \\
\mathbf{B}\end{array}$ & $\begin{array}{c}\text { Standardizál } \\
\mathbf{t} \\
\text { koefficiensek } \\
\text { Beta }\end{array}$ & $\mathbf{t}$ & $\mathbf{p}$ \\
\hline (Konstant) & 18,111 & & & \\
\hline SECQ - Szociális tudatosság & $-0,243$ & $-0,229$ & $-2,252$ & $0,026^{*}$ \\
\hline SECQ - Kapcsolatkezelés & 0,097 & 0,072 & 0,621 & 0,536 \\
\hline $\begin{array}{l}\text { SECQ - Kapcsolati } \\
\text { döntéshozás }\end{array}$ & 0,613 & 0,529 & 4,732 & $0,000^{* *}$ \\
\hline SDQ - Proszociális viselkedés & $-0,031$ & $-0,011$ & $-0,112$ & 0,911 \\
\hline
\end{tabular}

Megjegyzés: Korrigált $r^{2}=0,218 ; F(4)=8,821 ; p=0,000 * *$ 
Második hipotézisünkben feltételeztük, hogy az áldozati igazságosságra való érzékenység együttjár a deviáns magatartás megnyilvánulásával, a kedvezményezetti és az elkövetői igazságosságra való érzékenység pedig összefüggést mutat a proszociális hajlammal.

Korrelációs elemzést végezve megállapítottuk, hogy a kedvezményezetti és az elkövetöi igazságosságra való érzékenység összefügg a proszociális viselkedéssel, a Pearson-féle korrelációs együttható $\mathrm{r}=0,242 * * ; \mathrm{p}=0,010$; illetve $\mathrm{r}=0,304 * * ; \mathrm{p}=0,001$, míg az áldozati igazságosságra való érzékenység nem mutat együttjárást a viselkedési problémákkal $(\mathrm{r}=-0,039 ; \mathrm{p}=0,681)$. A következőkben két kategóriát hoztunk létre a proszociális viselkedés tekintetében, a magas, illetve az alacsony segítő magatartással rendelkezők csoportját. Összehasonlítást végezve a magas, illetve alacsony proszociális viselkedéssel jellemezhető egyének igazságosság iránti érzékenységében arra az eredményre jutottunk, hogy a magasabb proszociális viselkedéssel jellemezhető diákok átlagban magasabb kedvezményezetti és magasabb elkövetői igazságosságra való érzékenységgel rendelkeznek és a köztük lévő különbség mindkét esetben szignifikáns $(\mathrm{p}=0,030 *)$ (lásd 1. ábra).

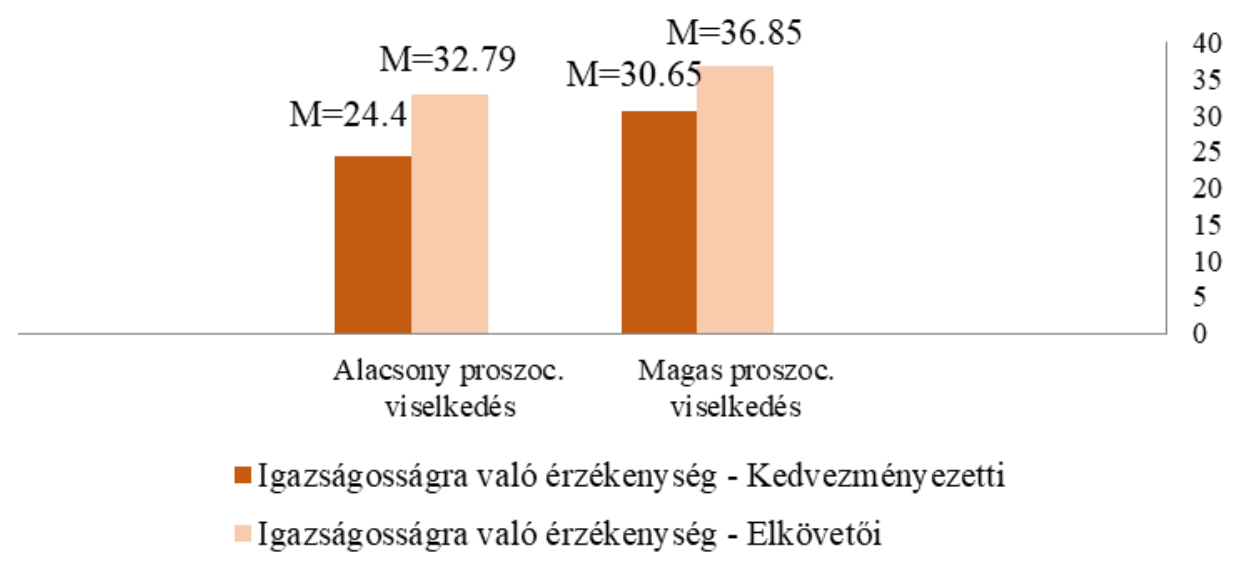

1. ábra. A magas és alacsony proszociális viselkedés különbségei a kedvezményezetti és az ez elkövetői igzaságosság tekintetében

Kutatásunk harmadik hipotéziseként feltételeztük, hogy a személyes igazságos világba vetett hit együttjárást mutat a tanulmányi teljesítménnyel. Azon vizsgálati személyek, akik magasabb személyes igazságos világba vetett hittel rendelkeznek jobb tanulmányi teljesítményt érnek el. Az eredmények értelmében egy gyenge, de szignifikáns együttjárás tapasztalható a személyes igazságos világba vetett hit és az előző félévi tanulmányi átlag között, a Pearson-féle korrelációs együttható $r=0.219^{*}, \mathrm{p}=0.020$.

Annak érdekében, hogy megvizsgáljuk, hogy a magasabb személyes igazságos világba vetett hit jobb tanulmányi teljesítményt eredményez-e, két kategóriába osztottuk a Személyes Igazságos Világba Vetett Hit Skálán kapott pontszámokat (magas és alacsony), majd ezeket összehasonlítottuk a diákok félévi tanulmányi átlagával. A kapott eredményeink szerint a magasabb személyes igazságos világba vetett hittel rendelkező egyének átlagban jobb tanulmányi átlaggal rendelkeznek, mint azon személyek, akiknél alacsonyabb a személyes igazságos világba vetett hit (lásd 2. Ábra). A két csoport között jelentős eltérés figyelhető meg a független mintás t-próba eredménye $t(111)=-2,206 ; p=0,029^{*}$. 


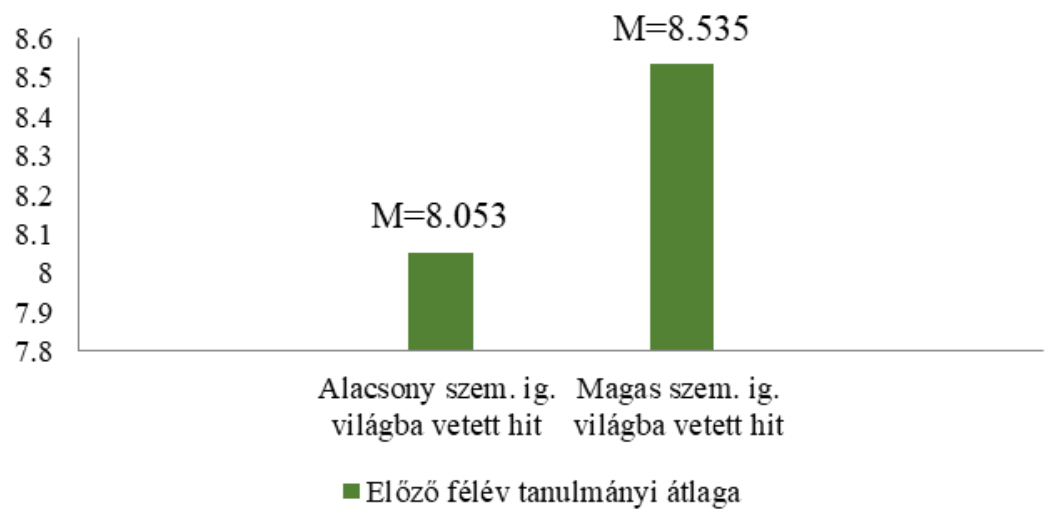

2. ábra. A tanulmányi átlagok közti különbség a magas és alacsony személyes igazságos világba vetett hit függvényében

A továbbiakban egyváltozós lineáris regressziós elemzéssel megvizsgáltuk, hogy a tanulmányi teljesítmény mennyiben jelzi elöre a személyes igazságos világba való hit alakulását. A kapott eredmények azt mutatják, hogy a modellbe bevont független változónk 4,0\%-ban magyarázza a függő változónk alakulását (lásd 3. táblázat).

3. táblázat. Egyváltozós lineáris regresszió a személyes igazságos világba vetett hit alakulásáról az előző féléves tanulmányi teljesítmény függvényében

\begin{tabular}{|c|c|c|c|c|}
\hline & $\begin{array}{c}\text { Standardizálatlan } \\
\text { koefficiensek } \\
\text { B }\end{array}$ & $\begin{array}{c}\text { Standardizált } \\
\text { koefficiensek } \\
\text { Beta }\end{array}$ & $\mathbf{t}$ & $\mathbf{p}$ \\
\hline Konstans & 20,730 & & & \\
\hline $\begin{array}{c}\text { Elözó félév } \\
\text { tanulmányi } \\
\text { eredménye }\end{array}$ & 0,976 & 0,219 & 2,369 & $0,020^{*}$ \\
\hline
\end{tabular}

Megjegyzés: Korrigált $r^{2}=0,040 ; F(1)=5,611 ; p=0,020 *$

Utolsó hipotéziseként feltételeztük, hogy a személyes igazságos világba vetett hit befolyást gyakorol a diákok és a hallgatók szubjektív jóllétére. A magasabb igazságos világba vetett hit magasabb szubjektív jóllétet eredményez. A személyes igazságos világba vetett hit és a szubjektív jóllét között egy közepesen erős együttjárás figyelhető meg, Pearson-féle korrelációs mutató $r=0,363 * * ; p=0,000$.

Az elemzés folytatásaként megvizsgáltuk, hogy a magasabb személyes igazságos világba vetett hit mutat-e különbséget a szubjektív jóllét tekintetében. Az eredményeink azt mutatják, hogy a magasabb személyes igazságos világba vetett hit magasabb szubjektív jólléti állapotot eredményez (lásd 3. Ábra) és a csoportok közötti különbség statisztikailag szignifikáns, amit a független mintás $\mathrm{t}$ próba eredménye mutat: $\mathrm{t}(111)=-3,381 ; \mathrm{p}=0,001^{*}$. 


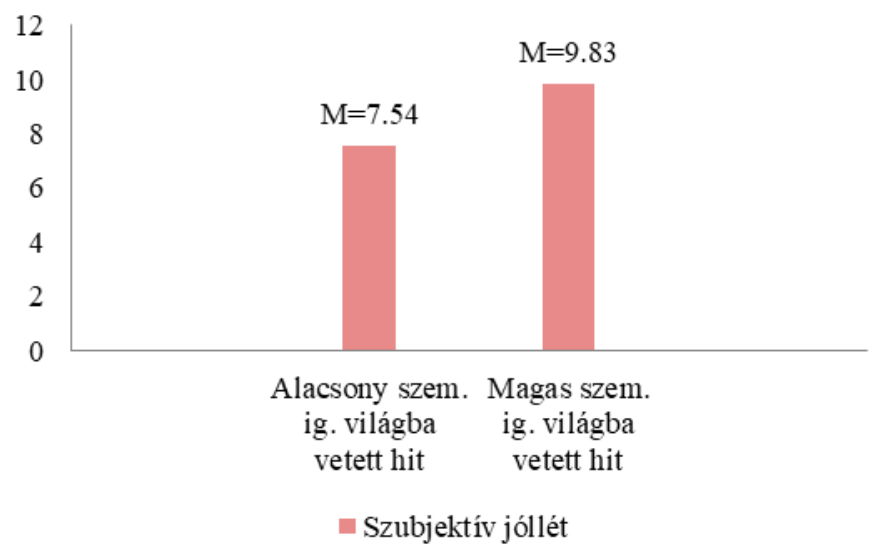

3. ábra. A magas és alacsony személyes igazságos világba vetett hit szubjektív jóllétre gyakorolt hatása

A továbbiakban lineáris regressziós elemzést hajtottunk végre, annak céljából, hogy megvizsgáljuk a szubjektív jóllét előrejelző funkcióval bír-e a személyes igazságos világba vetett hitre nézve (lásd 4. táblázat).

4. táblázat: Egyváltozós lineáris regresszió a személyes igazságos világba vetett hit alakulásáról a szubjektív jóllét függvényében

\begin{tabular}{|c|c|c|c|c|}
\hline & $\begin{array}{c}\text { Standardizálatlan } \\
\text { koefficiensek } \\
\text { B }\end{array}$ & $\begin{array}{c}\text { Standardizált } \\
\text { koefficiensek } \\
\text { Beta }\end{array}$ & $\mathrm{t}$ & $\mathrm{p}$ \\
\hline Konstans & 24,436 & & & \\
\hline WBI-5 & 0,509 & 0,363 & 4,104 & $0,000^{* *}$ \\
\hline
\end{tabular}

Megjegyzés: Korrigált $r^{2}=0,124 ; F(1)=18,846 ; p=0,000 * *$

A lineáris regresszióanalízis eredménye szerint a személyes igazságos világba vetett hitet 12,4\%-ban jelzi előre a személyek szubjektív jólléte.

\section{Az eredmények értelmezése és összegzés}

Jelen kutatásunk célja az volt, hogy feltárjuk az oktatási intézményekben, pontosabban az iskolások és az egyetemisták által észlelt és tapasztalt igazságosságot. A vizsgálni kívánt változónkat az igazságos világba vetett hit, valamint az igazságosság iránti érzékenység faktorain keresztül ragadtuk meg. Kutatásunk során arra voltunk kíváncsiak, hogy az igazságosság észlelése vagy éppen annak átélése milyen pszichológiai változásokat eredményez az illető személyeknél. Célunk tehát az volt, hogy feltárjuk az igazságosság iránti érzékenység és az igazságos világba vetett hit összefüggéseit a tanulók viselkedési megnyilvánulásával, szociális kompetenciájával, szubjektív jóllétükkel, valamint tanulmányi teljesítményükkel.

Kutatásunk során bizonyosságot nyert, hogy a személyes igazságos világba vetett hit fejlödésében fontos szerepet játszanak a társas kapcsolatok és a szociális kompetenciák, így feltételezhetjük, hogy az igazságosság gyökere a társadalmi normákból ered. Ezen megállapításunk alátámasztja Deutsch (1986) és Conry-Murray (2015) eredményeit, akik kutatásaik során azt találták, az igazságos bánásmód megnöveli az együttmüködés szándékát, valamint pozitívan hat a szociális kapcsolatokra. Sallay (2005) szerint az igazságos világba vetett hit segít a társas környezetben való eligazodásban, valamint a szociális interakciókon keresztül fejti ki hatását és marad fenn a társadalomban.

Ugyanakkor megállapítást nyert az a tény is, hogy az igazságosság iránti érzékenység bizonyos formája kapcsolatba hozható a proszociális viselkedéssel, amely szintén azt támassza alá, hogy az 
igazságosság fejlődésében kulcsszerepet játszanak a szociális interakciók. Az iskolákban, egyetemeken a személyes igazságos világba vetett hit nem csak a szociális kompetenciák alakulásában játszik szerepet, hanem meghatározza a diákok tanulmányi teljesítményét és szubjektív jóllétét, pozitív fejlődési irányba terelve ezeket. A kapott eredményeink egybehangzanak Berti Molinari és Speltini (2010), valamint Rosenbaum (2018) vizsgálatainak eredményeivel, akik szerint a személyes igazságos világba vetett hit megnöveli az iskolával szembeni elkötelezettséget, valamint jobb tanulmányi teljesítményt eredményez. Kamble és Dalbert (2012) eredményei szerint az erős igazságos világba vetett hit csökkenti az iskolai stresszt és a depressziós tünetek megjelenését, ezáltal kedvezőbb jóllétet eredményezve. Továbbá azt is megállapították, hogy az igazságos világba vetett hitnek kizárólag a személyes dimenziója járul hozzá a szubjektív jóllét növeléséhez.

Kutatásunk során választ kaptunk a címben szereplő kérdésre, mégpedig arra, hogy mindenki azt kapja-e, amit megérdemel. Azon személyek, akik hisznek abban, hogy viselkedésük, gondolkodásuk, cselekedeteik befolyásolják sorsuk alakulását, másokkal szemben is kedvezőbb bánásmódot mutatnak, hiszen a segítőkészség, az odafigyelés, a támogatás pozitív kimenetelt feltételez önmaguk irányába is. Ugyanakkor a tanulmányi teljesítményük is eredményesebb, hiszen nagyobb erőfeszítést mutatnak a munka iránt, mivel hisznek abban, hogy a befektetett munka meghozza a gyümölcsét.

\section{Irodalomjegyzék}

Berti, Ch., Molinari, L., \& Speltini, G. (2010): Classroom justice and psychological engagement: Students' and teachers' representations. Social Psychology of Education, 13(4), 541-556 Doi: 10.1007/s11218-010-9128-9.

Capone, V., Donizzetti, A. R., \& Petrillo, G. (2017): Classroom relationships, sense of community, perceptions of justice, and collective efficacy for students' social well-being. Journal of Community Psychology, 46(3), 374-382.

Chory, R. M., Houser, M. L., \& Horan, S. M. (2017): Justice in the Higher Education Classroom: Students' Perceptions of Unfairness and Responses to Instructors. Innovative Higher Education, 42(4), 321-336.

Conry-Muray, C. (2015): The Development of Social Justice: The Role of Reasoning. Human Development, 58(4-5), 273-280.

Csepeli Gy., Örkény A., Székelyi M., \& Barna I. (2004): Bizalom és gyanakvás. Szociálpszichológiai akadályok a piacgazdasághoz vezető úton Kelet-Európában. Szociológiai Szemle, 1, 3-35.

Dalbert, C. (1999): The World is More Just for Me than Generally: About the Personal Belief in a Just World Scale's Validity. Social Justice Research, 12, 79-98.

Dalbert, C., Montada, L., \& Schmitt, M. (1987): Belief in a just world: Validation correlates of two scales. Psychologiche Beitrage, 29, 596-615.

Deutch, M. (1986): Cooperation, Conflict, and Justice. In. H. W. Bierhoff, R. L. Cohen \& J. Greenberg (szerk.) Justice in Social Relations, Plenum Press, New York, 3-16.

Ehrhardt, N., Pretsch, J, \& Schmitt, M. (2018): Effects of Injustice in Primary Schools on Students' Behavior and Joy of Learning. Social Psychology of Education: An International Journal, 21(2), 337369.

Goodman, A., \& Goodman, J. (2009): Strengths and difficulties questionnaire as a dimensional measure of child mental health. J. Am. Acad. Child Adolesc Psychiatry, 48(4), 400-40.

Kamble, S. V., \& Dalbert, C. (2012): Belief in a just world and wellbeing in Indian schools. International Journal of Psychology, 47(4), 269-278.

Lane, J. (2000): A scientific approach for developing and testing a student's job-career plan before 11th grade. Education, 120, 605-613.

Lerner, M. J. (1980): The belief in a just world: A fundamental delusion. Plenum Press, New York 
Maxham, J. G., \& Netmeyer, R. G. (2002): Modeling customer perception of comlaint handling over time: the effects of perceived justice on satisfaction and intent. Journal of Retailing, 78, 239-252.

Molinari, L., Speltini, G., \& Passini, S. (2013): Do perceptions of being treated fairly increase students' outcomes? Teacher-student interactions and classroom justice. Educational Research and Evaluation, 19(1), 58-76.

Pikó B., \& Pinczés T. (2013): Az igazságosság élményének megitélése az iskolában serdülők körében. Debreceni Sportcentrum Kiemelkedően Közhasznú Nonprofit Kft., Debrecen

Pretsch, J., Risch, B., Ehrhardt, N., \& Roth, J. (2015): Injustice in School and Students' Emotions, Well-Being, and Behavior: A Longitudinal study. Social Justice Research, 29(1), 1-20.

Rawls, J. (1997): Az igazságosság elmélete. Osiris Kiadó, Budapest

Rosenbaum, J. (2018): Educational and Criminal Justice Outcomes 12 Years After School Suspension. Youth and Society, 42.

Sabbagh, C., \& Schmitt, M. (2016): Handbook of Social Justice Theory and Research. Springer, New York

Sallay, H. (2005): Serdülők szubjektív jólléte: A családban és a baráti kapcsolatban észlelt igazságosság és az igazságos világba vetett hit szerepe. Mentálhigénia és Pszichoszomatika, 6(4), 295 315.

Schmitt, M., Baumert, A., Gollwitzer, M., \& Maes, J. (2010): The justice sensitivity inventory: Factorial validity, location in the personality facet space, demographic pattern, and normative data. Social Justice Research, 23(2-3), 211-238.

Susánszky É., Konkoly T. B., Stauder A., \& Kopp M. (2006): A WHO jól-lét kérdõív rövidített (WBI5) magyar változatának validálása a Hungarostudy 2002 országos lakossági egészségfelmérés alapján. Mentálhigiéné és Pszichoszomatika, 7(3), 247-255. Doi: 10.1556/Mentál.7.2006.3.8.

Tomaka, J. \& Blascovich, J. (1994): Effects of justice beliefs on cognitive, psychological, and behavioral responses to potential stress. Journal of Personality and Social Psychology, 67, 732-740.

Weiss, H. M., Suckow, K., \& Cropanzano, R. (1999): Effects of Justice Conditions on Discrete Emotions. Journal of Applied Psychology, 84(5), 786-794.

Zhou, M., \& Ee, J. (2012): Development and Validation of the Social Emotional Competence Questionnaire (SECQ). The International Journal of Emotion Education, 4(2), 27-42

\section{Szerzők}

Bányai Blanka-Timea, Babeș-Bolyai Tudományegyetem, Alkalmazott Pszichológia Intézet, Kolozsvár (Románia), E-mail: blankabanyai@yahoo.com

Jancsó-Farcas Susana, Babeș-Bolyai Tudományegyetem, Alkalmazott Pszichológia Intézet, Kolozsvár (Románia), E-mail: zsuzsannapsy@gmail.com

\section{Köszönetnyilvánítás}

A jelen kutatás része Bányai Blanka-Timea mesteri disszertációjának, amit Jancsó-Farcas Susana irányításával végzett. 
